\title{
Etomidate and its Analogs: A Review of Pharmacokinetics and Pharmacodynamics
}

\author{
Beatrijs I. Valk ${ }^{1}$ Michel M. R. F. Struys ${ }^{1,2}$ (D)
}

Accepted: 11 May 2021 / Published online: 1 June 2021

(c) The Author(s) 2021

\begin{abstract}
Etomidate is a hypnotic agent that is used for the induction of anesthesia. It produces its effect by acting as a positive allosteric modulator on the $\gamma$-aminobutyric acid type A receptor and thus enhancing the effect of the inhibitory neurotransmitter $\gamma$-aminobutyric acid. Etomidate stands out among other anesthetic agents by having a remarkably stable cardiorespiratory profile, producing no cardiovascular or respiratory depression. However, etomidate suppresses the adrenocortical axis by the inhibition of the enzyme 11 $\beta$-hydroxylase. This makes the drug unsuitable for administration by a prolonged infusion. It also makes the drug unsuitable for administration to critically ill patients. Etomidate has relatively large volumes of distributions and is rapidly metabolized by hepatic esterases into an inactive carboxylic acid through hydrolyzation. Because of the decrease in popularity of etomidate, few modern extensive pharmacokinetic or pharmacodynamic studies exist. Over the last decade, several analogs of etomidate have been developed, with the aim of retaining its stable cardiorespiratory profile, whilst eliminating its suppressive effect on the adrenocortical axis. One of these molecules, ABP-700, was studied in extensive phase I clinical trials. These found that ABP-700 is characterized by small volumes of distribution and rapid clearance. ABP-700 is metabolized similarly to etomidate, by hydrolyzation into an inactive carboxylic acid. Furthermore, ABP-700 showed a rapid onset and offset of clinical effect. One side effect observed with both etomidate and ABP-700 is the occurrence of involuntary muscle movements. The origin of these movements is unclear and warrants further research.
\end{abstract}

\section{Introduction}

Etomidate is an imidazole-based agonist of the $\gamma$-aminobutyric acid type $\mathrm{A}\left(\mathrm{GABA}_{\mathrm{A}}\right)$ receptor used for the induction of general anesthesia and sedation. It was initially developed as an antifungal agent in 1964 by Janssen Pharmaceuticals, but during animal studies, its hypnotic effect was serendipitously observed [1]. It was introduced to clinical practice in Europe in 1972 [2] and was the first non-barbiturate intravenous anesthetic on the market [3].

Etomidate produces a swift onset of hypnotic effect, similarly to barbiturates and propofol, mainly through its action

Michel M. R. F. Struys

m.m.r.f.struys@umcg.nl

1 Department of Anesthesiology, University of Groningen, University Medical Center Groningen, Hanzeplein 1, 9713 GZ Groningen, The Netherlands

2 Department of Basic and Applied Medical Sciences, Ghent University, Ghent, Belgium

\section{Key Points}

Etomidate is a $\gamma$-aminobutyric acid type A receptor agonist used for the induction of anesthesia and is well known for its stable cardiorespiratory profile and its adrenal toxicity.

Recent pharmacokinetic and pharmacodynamic studies of etomidate are scarce.

Analogs of etomidate were developed over the last decade to improve upon the pharmacokinetic and pharmacodynamic profile of etomidate.

A recurrent side effect of etomidate and its analog ABP700 is the occurrence of involuntary muscle movements, the origin of which requires further research. 
on the $\mathrm{GABA}_{\mathrm{A}}$ receptor. It has no analgesic effect. A major advantage of etomidate is that it barely impacts the cardiovascular system. It produces minimal changes in systemic blood pressure and heart rate, which makes it an excellent drug to use in patients who are hemodynamically unstable, who have cardiac disease, $[4,5]$ or even those in hemorrhagic shock [6]. Other favorable properties of etomidate are that it causes little respiratory depression and no histamine release. Notable side effects of etomidate include postoperative nausea and vomiting, pain on injection, and myoclonic movements [7, 8] or involuntary muscle movements (IMM), during induction and emergence.

Up until 1983, etomidate was increasingly used as an intravenous anesthetic. In 1983, however, an increased mortality rate in patients who received etomidate was reported [9]. Several studies subsequently showed that etomidate caused adrenocortical suppression by the inhibition of the cytochrome P450 enzyme $11 \beta$-hydroxylase, making it unsuitable as a drug for the maintenance of anesthesia or sedation $[10,11]$. After these reports, etomidate use decreased and it was mainly reserved for the induction of anesthesia in patients who were hemodynamically unstable.

In the past decade, interest in etomidate was renewed as several research groups tried to alter the chemical structure of etomidate to create a novel anesthetic agent that would retain its favorable hemodynamic properties but lack its adrenocortical suppression [12-14]. Cyclopropyl-methoxycarbonyl-metomidate (CPMM, currently known as ABP-700) is one of the soft analogs of etomidate that is currently under development for use as an anesthetic agent. It was one of several soft analogs of etomidate designed to retain the favorable pharmacological properties of etomidate whilst diminishing its adrenal suppressive effects. This article aims to critically review and summarize the existing literature on the pharmacokinetics and pharmacodynamics of etomidate and its analogs, especially ABP-700.

\section{Methods}

The MEDLINE database was searched through PubMed. A search for English articles with a title or an abstract containing 'etomidate' in combination with 'pharmacokinetic(s)', 'pharmacodynamics(s)' and/or 'pharmacology', or with the medical subject heading (MeSH) term 'etomidate' combined with the MeSH terms 'hypnotics and sedatives/ pharmacology' or 'anesthetics, intravenous/pharmacology' yielded 696 results (as of September 2020). All abstracts were screened and when considered relevant, the paper's full text was obtained and saved in a Mendeley library [15]. Additional searches were performed including the keywords 'myoclonus', 'adrenal suppression', 'hepatic failure', 'renal failure', 'elderly', 'pediatric', 'neonate(s)', 'interactions', and 'etomidate analogue'. Bibliographies of articles were reviewed and as such, additional potentially relevant papers were identified and added to the library. The final library consists of 224 articles, of which 156 are used definitively for this review.

\section{Drug Formulation and Dosing}

Etomidate, or $R$-1-(1-ethylphenyl)imidazole-5-ethylester (Fig. 1), was originally synthesized as a racemic mixture, but it was found that the $\mathrm{R}(+)$-enantiomer had higher hypnotic potency [16]. Because etomidate is a weak base $\left(\mathrm{p} K_{\mathrm{a}}=4.5\right)$, it is hydrophobic at a physiologic $\mathrm{pH}$ of 7.4, and therefore badly soluble in aqueous solutions $[17,18]$. Currently, etomidate is clinically available in either a $0.2 \%$ solution in $35 \%$ propylene glycol (Hypnomidate ${ }^{\circledR}$; Janssen Pharmaceuticals, Beerse, Belgium; marketed in the USA as Amidate ${ }^{\circledR}$; Pfizer, New York, NY, USA) or as a lipid emulsion (Etomidate-Lipuro, Braun, Melsungen, Germany) [18, 19]. Standard dosing for the induction of anesthesia is $0.3 \mathrm{mg} / \mathrm{kg}$, after which hypnosis lasts for 5-10 min [20]. Alternative (off-label) dosing regimens that have been explored experimentally include oral transmucosal administration [21] and rectal administration [22].

The formulation of CPMM (or most frequently known as ABP-700, Fig. 2) is a $10-\mathrm{mg} / \mathrm{mL}$ solution, with $10 \%$ sulfobutylether- $\beta$-cyclodextrin as a solvent [23]. Bolus doses of $0.25 \mathrm{mg} / \mathrm{kg}$ and $0.35 \mathrm{mg} / \mathrm{kg}$ are found to be the most optimal doses for the induction of anesthesia [24], whereas an optimal continuous infusion dose has yet to be determined, although an infusion rate of $50 \mu \mathrm{g} / \mathrm{kg} / \mathrm{min}$ seems to have the

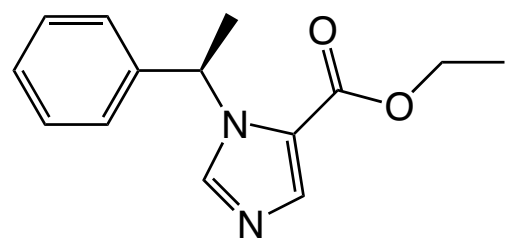

Fig. 1 Chemical structure of etomidate

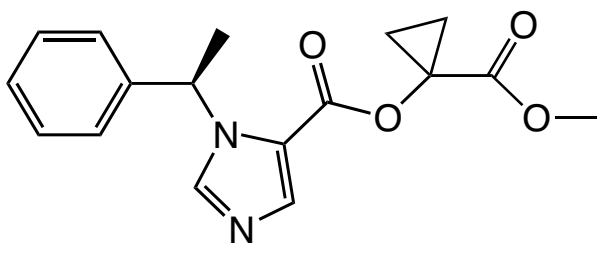

Fig. 2 Chemical structure of cyclopropyl-methoxycarbonyl-metomidate (or ABP-700) 
most optimal effect vs the side effect balance [23]. ABP-700 is currently under development.

\section{Pre-clinical Development of Etomidate Analogs}

In the development of analogs of etomidate, several strategies were applied to eliminate the adrenocortical suppression induced by etomidate. Prior to the development of ABP-700, the first analog of etomidate that was designed was methoxycarbonyl-etomidate (MOC-etomidate), a soft analog [12]. A soft analog is a molecule that is derived from a parent compound and is specifically designed to undergo predictable and rapid metabolism into inactive metabolites [25]. The objective of this molecule is to mostly alter the design of etomidate to enable ultra-rapid metabolism by non-specific esterases to a carboxylic acid by adding a new ester moiety that would be prone to fast hydrolysis. This would prevent it from binding to the hydrophobic catalytic site of the 11 $\beta$-hydroxylase enzyme [26] and thus, reduce the possibility of adrenocortical suppression. In vitro and in vivo studies of MOC-etomidate showed that it retains the rapid onset of hypnosis and hemodynamic stability of etomidate, and, because of ultra-rapid metabolism, causes ultra-rapid hypnotic recovery [12]. Additionally, $30 \mathrm{~min}$ after a single bolus administration, MOC-etomidate did not cause a significant reduction in the adrenocorticotropic hormone-stimulated serum corticosterone level in rats, whilst an equipotent dose of etomidate did so significantly. However, because of the ultra-rapid metabolism of MOC-etomidate, large quantities of drug were necessary to maintain an acceptable depth of anesthesia in rats and this in turn did lead to adrenocortical suppression [27]. Furthermore, equally large quantities of metabolite were being produced. Furthermore, despite the 300-fold lower potency of the metabolite of MOCetomidate, it was sufficient to produce burst suppression and cause a delayed recovery in rats $[28,29]$.

A pharmacodynamic solution for the occurrence of adrenocortical suppression through etomidate was also considered in the form of carboetomidate, a pyrrole-based sedative hypnotic analog of etomidate [13]. By designing out the imidazole ring thought to be responsible for adrenocortical suppression through an interaction with the heme-group in $11 \beta$-hydroxylase, adrenocortical suppression was indeed diminished. However, in rats, carboetomidate caused a relatively slow onset of hypnosis compared with etomidate, as it was less potent as a hypnotic. Hemodynamic stability was maintained during dosing [13].

Because the pharmacokinetic properties of MOC-etomidate were too fast, MOC-etomidate was adapted into 13 new analogs that attempted to slow down its fast pharmacokinetics. This was done by adding various aliphatic substituents onto the two-carbon spacer in MOC-etomidate, which would sterically protect the 'bare' ester moiety so that hydrolysis could slow down [30]. Of these 13 new analogs, two molecules, dimethylmethoxycarbonyl metomidate and cyclopropyl-methoxycarbonyl-metomidate (CPMM), showed high hypnotic potencies and a duration of action between that of MOC-etomidate and etomidate upon single bolus administration in rats. Upon prolonged infusions of both compounds, it was found that CPMM in particular demonstrated a context insensitive and swift recovery profile [31] and that adrenocortical suppression was significantly shorter than with etomidate [32].

In pharmacokinetic-pharmacodynamic (PK-PD) studies of CPMM in beagle dogs, similar pharmacokinetic and pharmacodynamic properties were observed: rapid metabolism, ultra-rapid hypnotic action, and a swift recovery profile, regardless of the duration of the infusion [33]. Furthermore, CPMM showed an adrenocortical recovery profile that was similar to that of propofol, the current standard of care, where 90 min after ending a continuous infusion of $2 \mathrm{~h}$, adrenocortical function was equivalent. One side effect observed during administration to beagle dogs was the occurrence of IMM, similar to what might be observed with etomidate. The incidence of these movements was higher during CPMM infusion than etomidate infusion. These movements could successfully be attenuated by midazolam [33]. Based on these promising pharmacological results, CPMM, or ABP-700 as it was called from that point onward, was put forward for clinical studies in healthy volunteers.

\section{Adverse Effects}

\subsection{Adrenal Suppression}

As mentioned previously, the most infamous side effect of etomidate, which has led to a significant reduction in its clinical use as a hypnotic, is the suppression of the adrenocortical axis. The first to report this side effect were Ledingham and Watt in 1983. They had observed an increase in mortality in critically ill patients who were mechanically ventilated and continuously sedated with etomidate vs patients who had been sedated with benzodiazepines ( $69 \%$ compared with $25 \%$, respectively) [9]. Around the same time, pre-clinical data emerged reporting that etomidate suppressed adrenocortical function in rats [34]. Furthermore, it was reported by McKee and Finlay that cortisol replacement therapy in critically ill patients had dramatically reduced mortality [35]. The clinical studies that followed suit confirmed this toxicity, showing that patients receiving etomidate as an intraoperative hypnotic had a decreased postoperative cortisol response to adrenocorticotropic hormone [10, 36]. In patients receiving a single bolus of etomidate, adrenal suppression lasted 6-8 h $[11,37]$, and in patients receiving a 
continuous infusion, this could last more than $24 \mathrm{~h}$ [38]. This was because etomidate was found to be a far more potent inhibitor of the adrenocortical axis than it is as a hypnotic. Plasma concentrations greater than $200 \mathrm{ng} / \mathrm{mL}$ were needed for adequate hypnosis, but concentrations less than $10 \mathrm{ng} /$ $\mathrm{mL}$ were associated with adrenal suppression [37]. After these findings, the clinical indication and use for etomidate were restricted to an anesthetic induction agent (single bolus only) in select patient groups with some academic publications even suggesting etomidate be removed from the clinic altogether $[39,40]$. The mechanism behind this suppression was found to be the interaction of the imidazole ring of etomidate with the cytochrome P450 enzyme 11 $\beta$-hydroxylase [10]. A high affinity interaction occurs between the basic nitrogen in this imidazole ring and the heme group, which the cytochrome P450 enzyme 11 $\beta$-hydroxylase contains [26]. During clinical studies for ABP-700, no suppression of the adrenal axis was observed and plasma cortisol levels were similar to placebo values $[23,24]$.

\subsection{Pain on Injection}

Pain on injection is a common side effect of etomidate. The extent of the pain and the incidence seems to be dependent on the size of the vein in which etomidate is injected [17], but also on the formulation used. The lipid emulsion, containing medium-chain and long-chain triglycerides, of Etomidate-Lipuro (Braun, Melsungen, Germany) [41, 42] is associated with a smaller incidence of pain on injection than that of hypnomidate/amidate, which is a $95 \%$ propylene glycol/water formulation. The mechanism behind such pain on injection is hypothesized to be the activation of transient receptor potential ion channels in the sensory neurons $[42,43]$. If the concentration of free aqueous etomidate is reduced, or by reducing osmolality, as is the case in lipid emulsions, transient receptor potential channel activation may also be reduced, thereby decreasing pain on injection. In clinical studies of ABP-700, pain on injection was also observed, but the incidence was relatively low, occurring in 2 out of 50 subjects after a bolus injection [24] and in 4 out of 25 subjects upon a continuous infusion of ABP-700 [23].

\subsection{Post-operative Nausea and Vomiting}

Postoperative nausea and vomiting are also associated with etomidate [7, 17], with incidences reported to be as high as $40 \%$. However, later studies comparing the lipid emulsion of etomidate to propofol found no significant difference in the incidence of post-operative nausea and vomiting. This suggests that the emetogenicity of etomidate lies in the formulation, rather than the anesthetic itself [44].

ABP-700 also shows emetogenic properties, although the incidence is relatively moderate compared with etomidate.
Upon a bolus study, two out of 50 subjects experienced post-operative nausea and vomiting [24], whereas during a continuous infusion, six out of 25 subjects experienced post-operative nausea and vomiting [23].

\section{Pharmacokinetics}

\subsection{Pharmacokinetics of Etomidate in Adults}

The pharmacokinetics of etomidate has been mainly described in studies carried out in the late 1970s and in the early 1980s, prior to the discovery that etomidate leads to significant adrenal suppression. In the period following this discovery, studies on the pharmacokinetic characteristics of etomidate are scarce, the only exception being a limited population pharmacokinetic model developed by Kaneda et al. [45]. For an overview of these studies, the reader is directed to Table 1; their model parameters are provided in Table 2.

\subsubsection{Absorption}

Etomidate is registered for intravenous use only. However, other routes of administration have been investigated, for sedative and/or anxiolytic purposes [21, 22]. Etomidate is reported to be well absorbed after oral transmucosal administration.

\subsubsection{Distribution}

Etomidate is $75 \%$ protein bound. In plasma, it binds solely to albumin [46]. Little is known about placental transfer of etomidate. A study in pregnant ewes showed that etomidate crosses the placenta rapidly, but a certain placental barrier of unknown etiology seems to limit its transfer [47]. The volumes of distribution of etomidate are relatively large, likely owing to its high solubility in fat, and seem to be related to body weight [48]. Depending on the number of compartments in the pharmacokinetic analysis, either two or three, volumes of distribution in steady state are reported to range from 0.15 to $4.7 \mathrm{~L} / \mathrm{kg}[45,48-53]$.

\subsubsection{Metabolism/Elimination}

Etomidate is metabolized to an inactive carboxylic acid metabolite [54]. This is primarily done by hepatic esterases, although it is thought that plasma esterases also play a small part in the hydrolyzation of etomidate. Reported hepatic extraction ratios range from 0.5 to $0.9[48,49]$. The metabolite is excreted in urine and for a small part in bile. Less than $2 \%$ of etomidate is excreted unchanged [54]. An elimination half-life of 2.9-5.5 h is reported in American Society of Anesthesiologists (ASA) class I/II patients [50, 


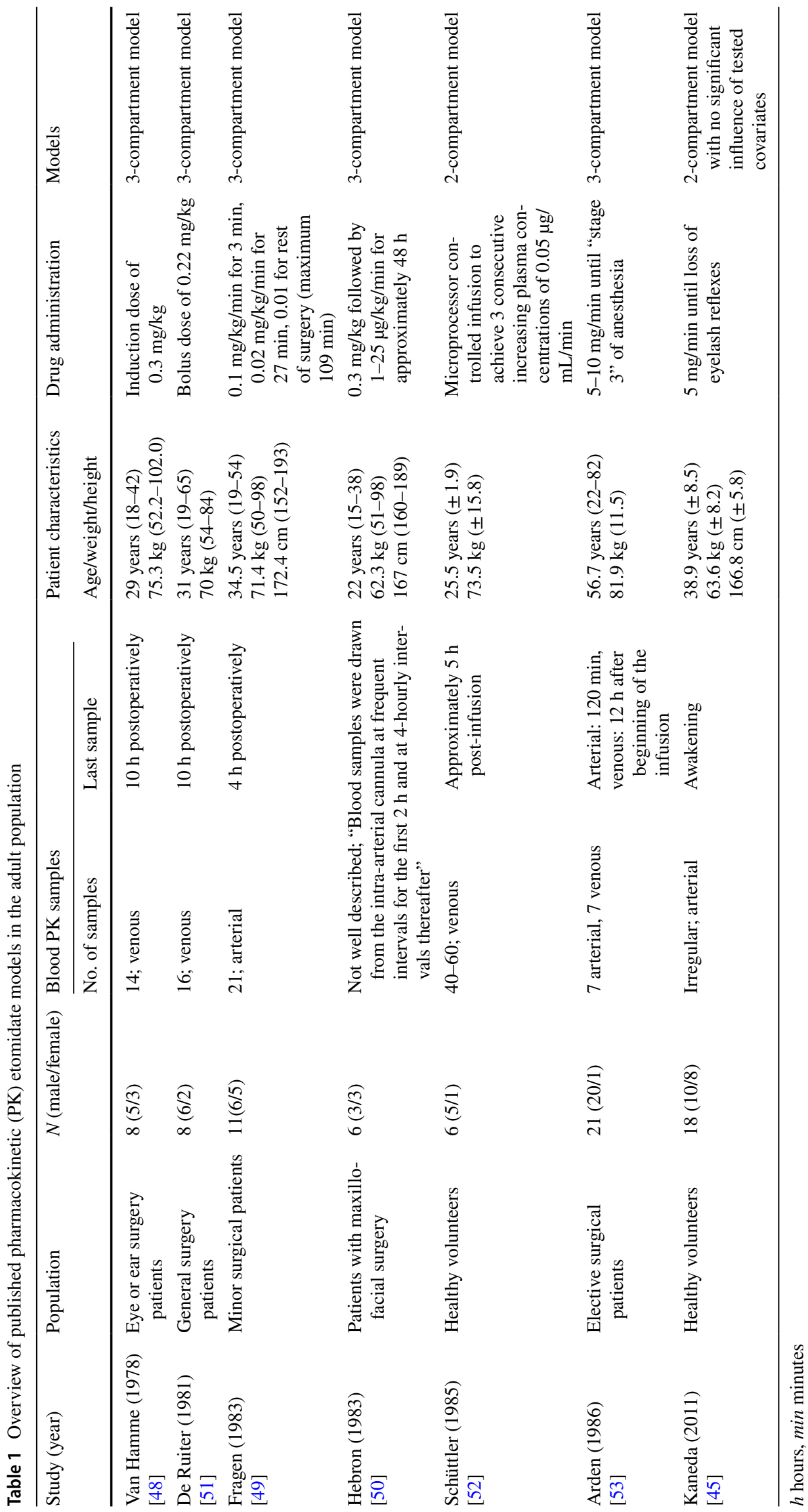


Table 2 Etomidate pharmacokinetic model parameters [mean \pm standard deviation or mean (standard error \%)]

\begin{tabular}{|c|c|c|}
\hline Reference (year) & Model parameters & Remark \\
\hline Van Hamme et al. (1978) [48] & $\begin{array}{l}\mathrm{Vc}(\mathrm{L} / \mathrm{kg}): 0.310 \pm 0.152 \\
k_{10}\left(\mathrm{~h}^{-1}\right): 2.774 \pm 1.386 \\
k_{12}\left(\mathrm{~h}^{-1}\right): 10.079 \pm 4.723 \\
k_{21}\left(\mathrm{~h}^{-1}\right): 5.464 \pm 2.119 \\
k_{13}\left(\mathrm{~h}^{-1}\right): 3.459 \pm 2.843 \\
k_{31}\left(\mathrm{~h}^{-1}\right): 0.453 \pm 0.210\end{array}$ & \\
\hline Fragen et al. (1983) [49] & $\begin{array}{l}\mathrm{Vc}(\mathrm{L} / \mathrm{kg}): 0.15 \pm 0.03 \\
\mathrm{~V} 2(\mathrm{~L} / \mathrm{kg}): 0.43 \pm 0.12 \\
\mathrm{~V} 3(\mathrm{~L} / \mathrm{kg}): 1.94 \pm 0.88 \\
\mathrm{Cl} 1(\mathrm{~mL} / \mathrm{min} / \mathrm{kg}): 17.9 \pm 5.6 \\
\mathrm{Cl} 2(\mathrm{~mL} / \mathrm{min} / \mathrm{kg}): 25.1 \pm 16.2 \\
\mathrm{Cl} 3(\mathrm{~mL} / \mathrm{min} / \mathrm{kg}): 5.7 \pm 2.1\end{array}$ & \\
\hline Hebron et al. (1983) [50] & $\begin{array}{l}\mathrm{Vc}(\mathrm{L} / \mathrm{kg}): 0.155 \\
k_{10}\left(\mathrm{~h}^{-1}\right): 0.687 \pm 0.089 \\
k_{12}\left(\mathrm{~h}^{-1}\right): 15.71 \pm 1.63 \\
k_{21}\left(\mathrm{~h}^{-1}\right): 4.31 \pm 1.02 \\
k_{13}\left(\mathrm{~h}^{-1}\right): 7.22 \pm 0.97 \\
k_{31}\left(\mathrm{~h}^{-1}\right): 0.687 \pm 0.089\end{array}$ & $\begin{array}{l}\mathrm{Vc} \text { is not reported in the paper and was calculated as the sum of } \\
\mathrm{A}, \mathrm{B} \text {, and } \mathrm{C} \text { from the poly-exponential equation }\end{array}$ \\
\hline De Ruiter et al. (1981) [51] & $\begin{array}{l}\mathrm{Vc}(\mathrm{L} / \mathrm{kg}): \text { not estimated in this study } \\
\mathrm{Vd}_{\text {area }}(\mathrm{L} / \mathrm{kg}): 3.68 \pm 0.66 \\
\mathrm{Vd}_{\text {steady state }}(\mathrm{L} / \mathrm{kg}): 2.16 \pm 0.32 \\
\mathrm{Cl}(\mathrm{L} / \mathrm{min}): 0.879 \\
t_{1 / 2 \alpha}(\min ): 2.83 \pm 2.35 \\
t_{1 / 2 \beta}(\min ): 22.3 \pm 10.4 \\
t_{1 / 2 \gamma}(\min ): 208.8 \pm 64.9\end{array}$ & $\begin{array}{l}\text { Model parameters based on both non-compartment and com- } \\
\text { partmental modeling }\end{array}$ \\
\hline Schüttler et al. (1985) [52] & $\begin{array}{l}\mathrm{Vc}(\mathrm{L}): 49.7 \pm 10.9 \\
k_{10}\left(\min ^{-1}\right): 0.036 \pm 0.010 \\
k_{12}\left(\min ^{-1}\right): 0.053 \pm 0.011 \\
k_{21}\left(\min ^{-1}\right): 0.020 \pm 0.003\end{array}$ & \\
\hline Arden et al. (1986) [53] & $\begin{array}{l}\mathrm{Vc}(\mathrm{L} / \mathrm{kg}): 0.090 \pm 0.027 \\
\mathrm{Vd}_{\text {steady state }}(\mathrm{L} / \mathrm{kg}): 4.7 \pm 1.8 \\
\mathrm{Cl} 1(\mathrm{~mL} / \mathrm{min} / \mathrm{kg}): 18.3 \pm 6.1 \\
\mathrm{Cl} 2(\mathrm{~mL} / \mathrm{min} / \mathrm{kg}): 25.5 \pm 8.2 \\
\mathrm{Cl} 3(\mathrm{~mL} / \mathrm{min} / \mathrm{kg}): 18.8 \pm 4.8 \\
t_{1 / 2 \alpha}(\mathrm{min}): 0.93 \pm 0.23 \\
t_{1 / 2 \beta}(\mathrm{min}): 12.1 \pm 5.1 \\
t_{1 / 2 \gamma}(\mathrm{min}): 324 \pm 162\end{array}$ & \\
\hline Kaneda et al. (2011) [45] & $\begin{array}{l}\text { Vc }(\mathrm{L}): 4.45(7.4)^{\mathrm{a}} \\
\text { V2 (L): } 74.9(41.7)^{\mathrm{a}} \\
\text { Cl1 (L/min): } 0.63(88.9)^{\mathrm{a}} \\
\text { Cl2 (L/min): } 3.16(21.4)^{\mathrm{a}}\end{array}$ & \\
\hline Lin et al. (2012) [56] & $\begin{array}{l}\mathrm{Vc}=\theta_{\mathrm{Vc}} \cdot(\operatorname{age} / 4)^{-0.451} \cdot(\mathrm{WT} / 70) \\
\mathrm{V} 2=\theta_{\mathrm{V} 2} \cdot(\mathrm{WT} / 70) \\
\mathrm{V} 3=\theta_{\mathrm{V} 3} \cdot(\text { age } / 4)^{-0.23} \cdot(\mathrm{WT} / 70) \\
\mathrm{Cl} 1=\theta_{\mathrm{Cl} 1}(1-(\mathrm{age}-4) 0.0288) \cdot(\mathrm{WT} / 70)^{0.75} \\
\mathrm{Cl} 2=\theta_{\mathrm{Cl} 2} \cdot(\mathrm{WT} / 70)^{0.75} \\
\mathrm{Cl} 3=\theta_{\mathrm{Cl} 3} \cdot(\mathrm{WT} / 70)^{0.75} \\
\text { Estimates are: } \\
\mathrm{Vc}(\mathrm{L}): 9.51(10.4)^{\mathrm{a}} \\
\mathrm{V} 2(\mathrm{~L}): 11.0(16.0)^{\mathrm{a}} \\
\mathrm{V} 3(\mathrm{~L}): 79.2(11.0)^{\mathrm{a}} \\
\mathrm{Cl} 1(\mathrm{~L} / \mathrm{min}): 1.50(4.0)^{\mathrm{a}} \\
\mathrm{Cl} 2(\mathrm{~L} / \mathrm{min}): 1.95(10.6)^{\mathrm{a}} \\
\mathrm{Cl} 3(\mathrm{~L} / \mathrm{min}): 1.23(6.7)^{\mathrm{a}}\end{array}$ & This is the full covariate model including allometric scaling \\
\hline Su et al. [57] & $\begin{array}{l}\text { Vc }(\mathrm{L} / 70 \mathrm{~kg}): 8.07(11.6)^{\mathrm{a}} \\
\text { V2 }(\mathrm{L} / 70 \mathrm{~kg}): 22.8(23.6)^{\mathrm{a}} \\
\text { Cl1 }(\mathrm{L} / \mathrm{min} / 70 \mathrm{~kg}): 0.466(15.5)^{\mathrm{a}} \\
\text { Cl2 }(\mathrm{L} / \mathrm{min} / 70 \mathrm{~kg}): 0.289(17.5)^{\mathrm{a}}\end{array}$ & \\
\hline
\end{tabular}


Table 2 (continued)

\begin{tabular}{lll}
\hline Reference (year) & Model parameters & Remark \\
\hline Shen et al. [58] & $\mathrm{Vc}=\theta_{\mathrm{Vc}} \bullet(\mathrm{WT} / 70)$ & This is the full covariate model including allometric scaling \\
$\mathrm{V} 2=\theta_{\mathrm{V} 2} \bullet(\mathrm{WT} / 70)$ & TOF $=0$ and 1 for children with and without TOF \\
$\mathrm{V} 3=\theta_{\mathrm{V} 3} \bullet(\mathrm{WT} / 70)$ & \\
$\mathrm{Cl} 1=\theta_{\mathrm{Cl1}} \bullet 0.733^{\mathrm{TOF}} \cdot(\mathrm{WT} / 70)^{0.75}$ & \\
$\mathrm{Cl} 2=\theta_{\mathrm{Cl} 2} \bullet(\mathrm{WT} / 70)^{0.75}$ & \\
$\mathrm{Cl} 3=\theta_{\mathrm{Cl}} \bullet(\mathrm{WT} / 70)^{0.75}$ & \\
$\mathrm{Estimates}$ are: & \\
$\mathrm{Vc}(\mathrm{L}): 8.07(14)^{\mathrm{a}}$ & \\
$\mathrm{V} 2(\mathrm{~L}): 13.7(11.4)^{\mathrm{a}}$ & \\
$\mathrm{V} 3(\mathrm{~L}): 41.9(22.9)^{\mathrm{a}}$ & \\
$\mathrm{Cl} 1(\mathrm{~L} / \mathrm{min} /): 1.31(10.4)^{\mathrm{a}}$ & \\
$\mathrm{Cl} 2(\mathrm{~L} / \mathrm{min}): 1.91(12.5)^{\mathrm{a}}$ & \\
$\mathrm{Cl} 3(\mathrm{~L} / \mathrm{min}): 0.322(17.7)^{\mathrm{a}}$ & \\
$\mathrm{TOF}$ effect on $\mathrm{Cl} 1=0.733(12.9)^{\mathrm{a}}$ & \\
\hline
\end{tabular}

$\mathrm{Cl1}$ clearance of the central compartment or elimination clearance, $\mathrm{Cl} 2$ clearance from the second compartment, $\mathrm{Cl} 3$ clearance from the third compartment, $h$ hour, $k_{10}, k_{12}, k_{21}, k_{13}, k_{31}$ intercompartmental distribution constants, min minutes, $t_{1 / 2 \alpha}$ rapid distribution half-life, $t_{1 / 2 \beta}$ slow distribution half-life, $t_{1 / 2 \gamma}$ terminal elimination half-life, TOF tetralogy of Fallot, $V 2$ volume of distribution of the second or fast equilibrating compartment, $V 3$ volume of distribution of the third or slow equilibrating compartment, $V c$ central volume of distribution, $W T$ represents weight (kg) ${ }^{a}$ Mean (standard error \%)

51]. Reported systemic clearances are very variable, with a range from $9.9 \mathrm{~mL} / \mathrm{min} / \mathrm{kg}$ to $25.0 \mathrm{~mL} / \mathrm{min} / \mathrm{kg}[45,50]$. In elderly patients, smaller doses of etomidate are required because of reduced protein binding and reduced clearance. This is also the case in patients with renal failure or hepatic cirrhosis $[53,55]$.

\subsection{Pharmacokinetics of Etomidate in Children}

The pharmacokinetics of etomidate in the pediatric population is described for children aged over 6 months by Lin et al. [56] in patients who underwent elective surgery. Su et al. [57] and Shen et al. [58] focused on the pharmacokinetics of etomidate in neonates and infants aged younger than 12 months with congenital heart disease. For an overview of these studies, the reader is directed to Table 3; their model parameters are provided in Table 2. In the studies by Lin et al. and $\mathrm{Su}$ et al., etomidate was administered as a bolus of $0.3 \mathrm{mg} / \mathrm{kg}$, after which anesthesia was maintained using a combination of volatile anesthetic agents and fentanyl $[56,57]$. Shen et al. chose to administer etomidate at an infusion rate of $60 \mu \mathrm{g} / \mathrm{kg} / \mathrm{min}$ until a bispectral index (BIS) of 50 was reached for $5 \mathrm{~s}$. Maintenance of anesthesia was achieved here with a combination of the volatile anesthetic agent sevoflurane, intravenous anesthetic agent propofol, and the opioid sufentanil [58]. Lin et al. and Shen et al. found that a three-compartment model using allometric scaling best described the pharmacokinetics of etomidate, although the allometric model of Shen et al. was only slightly superior to their linear model $[56,58]$. Conversely, Su et al. found that a two-compartment model with allometric scaling described the pharmacokinetics of etomidate best [57]. Lin et al., the only pediatric model studying patients aged older than 6 months, found that age was the most significant pharmacokinetic covariate, with a higher age resulting in a smaller (size-adjusted) clearance and volumes of distribution. Both Shen et al. and Su et al. studied the effect of cardiac anatomy and physiology on the pharmacokinetics of etomidate in neonates and infants. Su et al. found no effect of these covariates on their model performance. However, Shen et al. identified the occurrence of the tetralogy of Fallot as a covariate affecting mostly the clearance of etomidate, resulting in lower clearances compared with children with normal cardiac anatomy. There is a large variability in pharmacokinetic parameters found in these three studies. Lin et al. report almost a three-fold higher clearance than $\mathrm{Su}$ et al. Su et al. suggested that because Lin et al. mainly studied an older pediatric population, their model might be inappropriate to apply to neonatal and infant populations. As there are scarce data on the adult population pharmacokinetics, it is difficult to relate the findings in these three pediatric studies to pharmacokinetic properties of etomidate in adults.

\subsection{Pharmacokinetics of ABP-700}

The novel anesthetic agent and etomidate analog ABP-700 is rapidly hydrolyzed by non-specific esterases into pharmacologically inactive metabolite, CPM-acid, and ethanol [24]. The pharmacokinetics was recently described using a recirculatory model, with applied allometry [59]. Volumes of distribution were relatively small, indicating a small extent of accumulation, and clearance was rapid at $1.95 \mathrm{~L} / \mathrm{min}$ for a 70-kg, 35-year-old male individual. This results in rapidly stabilizing drug concentrations and rapidly decreasing drug concentrations after stopping administration. The metabolite, CPM-acid has a comparatively low systemic clearance, 
of $0.769 \mathrm{~L} / \mathrm{min}$, which may result in high plasma concentrations with prolonged infusions, unlikely to have any clinical effect [59].

\section{Pharmacodynamics}

\subsection{CNS}

\subsubsection{Hypnotic Action}

Etomidate produces a swift onset of anesthesia. Following a single bolus of etomidate, loss of eyelash reflex occurs within $116 \mathrm{~s}$ and anesthetic-level electro-encephalographic activity as measured by the BIS reaching a value of 50 , is observed within $150 \mathrm{~s}$, regardless of dose. [60] A continuous infusion of $0.06 \mathrm{mg} / \mathrm{kg} / \mathrm{min}$ of etomidate causes loss of consciousness within $6 \mathrm{~min}$, which is faster than equipotent doses of other anesthetic agents, such as propofol [61]. ABP700 demonstrates an even more rapid onset of action, with loss of consciousness almost occurring immediately after a bolus dose [24] and a dose-dependent loss of consciousness upon a continuous infusion [23].

Although clinical studies of etomidate are relatively scarce compared with for example propofol or isoflurane, the molecular pharmacology of etomidate is well understood [62]. Etomidate, like the barbiturates and propofol, produces its hypnotic effect by acting as a positive allosteric modulator of the $\mathrm{GABA}_{\mathrm{A}}$ receptor [63]. The $\mathrm{GABA}_{\mathrm{A}}$ receptor is the major inhibitory receptor in the mammalian central nervous system (CNS) [64]. It solely binds to the $\beta+/ \alpha$-interface of the receptor $[65,66]$ and whilst most general anesthetics show little selectivity for the different $\mathrm{GABA}_{\mathrm{A}}$ receptor subtypes, etomidate selectively enhances the GABA response of receptors containing the $\beta 2$ or $\beta 3$ subunits [67]. The $\mathrm{GABA}_{\mathrm{A}}$ receptor produces its effect when it is activated by the matching neurotransmitter, GABA. The receptor undergoes a conformational change, allowing the center ion channel pore to open. This permits chloride ions to pass from the extracellular to the intracellular space, resulting in hyperpolarization of the neuron, inhibiting the activity of that particular cell [68].When anesthetic agents bind to a certain site somewhere on the receptor, it enhances the response of the receptor to GABA, thus enhancing the inhibiting effect on the CNS. At high concentrations, these anesthetics can directly activate the receptor opening [69]. These anesthetic agents are the positive allosteric modulators of the $\mathrm{GABA}_{\mathrm{A}}$ receptor. The mechanism behind and the extent of this enhancement depends on the anesthetic and its binding site on the $\mathrm{GABA}_{\mathrm{A}}$ receptor and is also dependent on the dose of the anesthetic [68]. ABP-700 is, as a secondgeneration analog of etomidate, also a positive allosteric 
modulator of the $\mathrm{GABA}_{\mathrm{A}}$ receptor, and binds to the same site on the $\mathrm{GABA}_{\mathrm{A}}$ receptor as etomidate [70].

Although the molecular effects of etomidate, and anesthetic agents in general, are mostly well understood, a lack of knowledge about the translation of the molecular effects of etomidate to the alteration of synaptic and neural functions and the production of the hypnotic effect still exists. This can be partly attributed to the fact that there is no generally accepted theory of the mechanism of unconsciousness [71]. In recent years, several brain areas that seem to be involved in the generation of consciousness, unconsciousness, sleep, and anesthesia have been identified. The reticular formation of the brainstem contains several sleep-promoting and wakefulness-promoting cholinergic and monoaminergic nuclei that affect higher cortical structures and whose activity and reciprocal influence changes, depending on the level of consciousness [72-74]. Wakefulness-promoting areas include the locus coeruleus, the dorsal raphe, pontis oralis, and the centromedial thalamus. Inactivation of some of these areas enhances anesthesia, whereas activation can enhance emergence from anesthesia. Sleep-promoting areas include the ventrolateral preoptic area. It has been reported that lesions in this area can increase the level of wakefulness [75]. High concentrations of anesthetic agents affect these nuclei and this might lead to clinical unconsciousness.

Another area that potentially plays a role in the mechanism behind anesthesia is the thalamus, responsible for information processing within the brain. Under general anesthesia with propofol, a decrease in cerebral blood flow, activity, and metabolism has been observed in this area. It is still unknown whether this observation is a cause or a consequence of the hypnotic action of anesthetic agents, although several theories and hypotheses have been published [76-80]. It has been established that the cerebral cortex is also a crucial effect target for anesthetic agents, as several studies have demonstrated a decrease in cortical activity and cerebral blood flow in this area during sedation and general anesthesia [81].

\subsubsection{Combined PK-PD Modeling}

Because of its restricted use as an anesthetic induction agent and the potential contamination of the BIS monitor by IMM [82], population combined PK-PD models of etomidate are scarce. Kaneda et al. [45] developed a sigmoid $E_{\max }$ model in which the $\mathrm{EC}_{50}$ value was 0.526 for BIS, with a $\gamma$ of 2.25 . The $k_{\mathrm{e} 0}$ of etomidate was 0.447 per minute. However, the sample size was small at 18 healthy volunteers, and blood sampling times were irregular.

Valk et al. [59] recently developed a PK-PD model based on data gathered from 266 subjects who had received ABP700. Where usually PK-PD models have a single (mathematical) effect side, i.e., production of anesthesia, Valk et al. found that in the pharmacodynamic model to describe BIS, a secondary effect site had to be incorporated that accounted for excitatory or disinhibitory activity to produce a good model fit. This secondary effect site acts in opposition to the primary effect site of BIS suppression, i.e., the production of anesthesia. The $\mathrm{EC}_{50}$ for BIS suppression was $1014 \mathrm{ng} /$ $\mathrm{mL}$, whereas the $\mathrm{EC}_{50}$ for excitation was $1230 \mathrm{ng} / \mathrm{mL}$. The rapid onset of action of ABP-700 was underlined by the $k_{\mathrm{e} 0}$ of $0.844 / \mathrm{min}$ [59].

\subsubsection{IMM}

One of the most pronounced side effects of both etomidate and analogs such as ABP-700 is the dose-dependent occurrence of IMM and/or myoclonus. These movements can range from mild movement of a single extremity to fullbody twitching and myoclonus, which can potentially negatively affect the patient's procedure. The incidence of these movements in etomidate is reported in some studies in nonpremedicated patients to be $80 \%$. This same incidence was observed during clinical trials in which non-premedicated healthy volunteers received ABP-700 [23, 24]. Several strategies have been studied to reduce the incidence of these movements. They can be reduced or prevented by pre-medication of the patients receiving etomidate with CNS depressant effects. These include opiates (fentanyl, remifentanil) [83-86], benzodiazepines [87, 88], dexmedetomidine [89, 90], thiopental [89], lidocaine [91], and magnesium [92]. Another strategy is a split-dose infusion of etomidate as a 'primer dose' [93, 94].

The origin of these movements is not yet clear; however, it is unlikely that they are of epileptogenic etiology [93]. Several clinical studies have studied the electroencephalogram (EEG) during administration of etomidate and have found that IMM do not coincide with epileptiform paroxysms [93, 95-97]. For ABP-700, no clinical "full-montage" EEG studies were performed so far. In toxicology studies in 14 Beagle dogs, in which supra-clinical doses of ABP-700 were administered, both IMM and seizures were observed. However, these phenomena were distinct temporally and eletroencephalographically. The seizures that were experienced by five out of 14 Beagle dogs occurred after the infusion of ABP-700 had been terminated. Conversely, the IMM that were experienced by all 14 dogs occurred during the infusion, during which no seizure activity was observed [98]. Further electrophysiological studies observed that high concentrations of the metabolite of ABP-700, CPM-acid, could produce inhibition of the $\mathrm{GABA}_{\mathrm{A}}$ receptor, a wellknown mechanism of seizures. These concentrations were observed in the dogs, and thus it was concluded that these post-infusion seizures were most likely produced by the metabolite. The concentration of CPM-acid needed to cause inhibition of the $\mathrm{GABA}_{\mathrm{A}}$ receptor is about 100 -fold higher 
than the highest concentration observed in clinical studies of ABP-700 [98]. Therefore, it is extremely unlikely that the healthy volunteers in these clinical studies experienced seizures based on high concentrations of CPM-acid, or that the IMM are of epileptogenic etiology. Further clinical studies using a full-montage EEG are necessary to definitively exclude a convulsive etiology of these IMM.

Doenicke et al. and Kugler et al. hypothesized that the origin of IMM observed in etomidate lies in a temporary disequilibrium of the drug at effect sites within the CNS [93]. This hypothesis postulates that low concentrations of an anesthetic drug depress inhibitory neuronal circuits earlier than the excitatory neuronal circuits. Possible explanations for this disequilibrium are differences in local cerebral blood flow or differences in affinity [96]. This is supported by the observations of several studies that CNS-depressing pre-treatment reduces the incidence of IMM (see before) and that higher dosages of etomidate and ABP-700 produce more IMM.

In the PK-PD model of ABP-700 developed by Valk et al., the secondary effect site mentioned previously was associated with a risk of occurrence of IMM. Lower values of $\mathrm{EC}_{50}$ of this disinhibitory effect site were observed in individuals who also experienced more severe IMM. The $\mathrm{EC}_{50}$ for this effect site was higher in individuals who received pre-medication with opioids or benzodiazepines [59] This observation supports the hypothesis by Doenicke et al. and Kugler et al. that an unsynchronized onset of drug effect exists at different effect sites within the CNS.

What then, in turn, might be the cause of this disequilibrium in drug effect? It is likely that on a molecular level, IMM are modulated by the $\mathrm{GABA}_{\mathrm{A}}$ receptor. McGrath et al. demonstrated that when the structure of etomidate is modified to eliminate its $\mathrm{GABA}_{\mathrm{A}}$ positive modulatory activity, IMM are no longer observed in rats [99]. Note that in the PK-PD model of Valk et al. there also seems to be an interindividual variability in the susceptibility to IMM. There are several explanations for this inter-individuality that might also explain the disequilibrium in drug effect. One is that there is a difference in the distribution of $\mathrm{GABA}_{\mathrm{A}}$ receptor subtypes [69]. Because etomidate, and by extension ABP700 , binds very specifically on the $\mathrm{GABA}_{\mathrm{A}}$ receptor, different distribution of subtypes within the CNS might cause higher susceptibility to IMM. Another explanation could be that with etomidate and ABP-700 being rapid-onset drugs, there might be an inter-individual variability in drug distribution and/or metabolism [59].

\subsection{Cardiovascular Effects}

A major advantage of etomidate compared with other anesthetic agents is that it preserves cardiovascular stability.
It typically does not cause significant hypotension upon induction of anesthesia at a dose of $0.3 \mathrm{mg} / \mathrm{kg}$. This is because etomidate does not significantly inhibit sympathetic tone and preserves autonomic reflexes, such as the baroreflex [100]. It is thought that etomidate has this property because it acts as an agonist at the $\alpha_{2}$-adrenoceptors, in particular the $\alpha_{2 \mathrm{~B}}$-adrenoreceptor responsible for the peripheral vasoconstrictive response to hypotensive effects [101]. In healthy patients, multiple studies show that anesthetic induction doses of etomidate cause minimal changes in heart rate $(<10 \%)$, preserving other hemodynamic parameters such as central venous pressure, pulmonary artery pressure, cardiac index, and systemic vascular resistance $[2,5,102-104]$. This beneficial cardiovascular profile makes etomidate a suitable anesthetic induction agent for patients who are hemodynamically unstable or who have cardiac disease. In patients with valvular heart disease or coronary artery disease, anesthetic induction doses of etomidate have a minimal effect on hemodynamic parameters [103, 105]. Myocardial contractility and myocardial oxygen supply-to-demand ratio are not impaired by etomidate [106]. Because of the preservation of sympathetic tone and autonomic reflexes and the lack of analgesic action, responses to laryngoscopy and endotracheal intubation are not blunted by etomidate. This can lead to an increase in arterial pressure and heart rate. In a direct BIS-guided comparison between propofol and etomidate in 46 ASA class III patients, etomidate was associated with a higher incidence in hypertension, a higher cardiac index, and a higher heart rate after intubation stimulus, whereas propofol was associated with a higher incidence of hypotension [107]. To obtain a satisfactory blunting of sympathetic response, an adequate management of opioid co-administration is needed. The relative cardiovascular stability of etomidate makes it a suitable anesthetic induction agent to use in the setting of hemorrhagic shock. Several animal models of hemorrhagic shock show that etomidate has a favorable impact on the cardiovascular system in a state of hypovolemia, decreasing mean arterial pressure and heart rate, and increasing systemic vascular resistance. Pharmacokinetic and pharmacodynamic profiles of etomidate are barely impacted by hemorrhagic shock [108, 109].

Like etomidate, ABP-700 maintains cardiovascular stability. Studies in human volunteers showed that especially in higher dosages, ABP-700 is associated with an increase in systolic blood pressure, whilst maintaining diastolic blood pressure, and an increase in heart rate [23, 24]. These phenomena occurred without laryngoscopy or endotracheal intubation triggers. However, higher ABP-700 dosages were also associated with 'excitatory' phenomena such as IMM. As such, it is possible that this cardiovascular hyperdynamic is caused by a general excitatory state. 


\subsection{Respiratory Effects}

Compared with other anesthetics, such as propofol and barbiturates, etomidate has a smaller impact on the respiratory system. After induction of anesthesia with etomidate at a dose of $0.3 \mathrm{mg} / \mathrm{kg}$, a short period of hyperventilation occurs. Several studies in patients reported a brief period of apnea $[110,111]$, with a mean duration of $20 \mathrm{~s}$ [17]. These apnea periods result in a change in $\mathrm{PaCO}_{2}$ of $\pm 15 \%$ and have no significant effect on $\mathrm{PaO}_{2}$ [105]. The occurrence of apnea following anesthetic induction doses of etomidate also seem to depend on the type of premedication applied prior to etomidate administration. Compared with methohexital, etomidate causes a less pronounced depression of ventilatory response to $\mathrm{CO}_{2}$ [111]. No histamine release occurs upon administration of etomidate $[112,113]$.

ABP-700 has a respiratory profile that is similar to that of etomidate. In the more than 350 volunteers who received ABP-700, only short-lasting episodes of apnea occurred and none was clinically relevant $[23,24,59]$. Ventilatory frequency was higher in subjects receiving ABP-700 compared with control groups receiving placebo and propofol. However, $\mathrm{PaCO}_{2}$ did not change significantly.

\section{Special Populations}

\subsection{Critically III Patients}

Because of its relatively stable cardiovascular profile, etomidate is sometimes used as an anesthetic induction agent in critically ill patients. As mentioned previously, etomidate causes suppression of the adrenal axis, which caused it to be no longer used for the maintenance of anesthesia or sedation. The use of a single dose of etomidate in critically ill patients, however, is also controversial $[114,115]$. Conflicting evidence about the potential benefits of etomidate vs its potential detriments in this particular patient group exists in the literature. Studies investigating the relationship between the duration of adrenal insufficiency after a single dose of etomidate and the general outcome reported that adrenal suppression after etomidate administration lasts longer than $24 \mathrm{~h}$ [116]. The clinical impact of this adrenal suppression, however, is currently unclear [117]. Concerns about the adrenal toxicity of etomidate in critically ill patients reemerged in the early 2000s after exposure to a single dose of etomidate was found to be a confounding variable in a large multicenter trial studying the effect of corticosteroid replacement therapy in patients with sepsis with relative adrenal insufficiency [118]. In this study, of the 70 patients receiving a single dose of etomidate, 68 did not respond adequately to corticosteroid replacement therapy [119]. In a follow-up study in 477 patients with severe sepsis, the Corticosteroid Therapy of Septic Shock (CORTICUS) study, a single dose of etomidate was associated with a $60 \%$ non-response rate to corticosteroid replacement therapy, which was significantly higher than the non-response rate of patients who did not receive etomidate [120,121]. Retrospective studies of the CORTICUS cohort suggested that etomidate was also associated with a worse outcome, as the 28-day mortality was significantly higher in patients who had received etomidate [120-122]. Conversely, a large prospective study on the effect of etomidate on the mortality and hospital length of stay of patients with sepsis could not identify a significant increase of both endpoints in patients who received etomidate vs those who did not [123]. In critically ill patients without sepsis, a consensus about the clinical effect of the adrenal suppression of a single dose of etomidate also does not exist. Hildreth et al. and Komatsu et al. both reported an increased length of stay after induction of anesthesia with etomidate in trauma patients and ASA class III and IV patients, respectively [124, 125]. Meanwhile other studies did not find significant differences in outcomes in emergency patients [126, 127]. Currently, alternative anesthetic induction agents, such as ketamine, are being studied and found to be a viable alternative to etomidate [126, 128-130]. However, large clinical trials are needed to define the clinical impact of a single dose of etomidate in critically ill patients, both with and without sepsis [62].

\subsection{Pediatrics}

In children, etomidate is generally safe as an induction agent [20]. Similar to the adult population, a single induction dose of etomidate also suppresses the adrenal axis in children $[131,132]$ and etomidate is not suitable for prolonged infusion. Etomidate in children is mainly used in the emergency department [133-135] and in children with congenital heart disease [57, 58, 136, 137]. For the pharmacokinetics of etomidate in children, see Sect. 6.3.

\subsection{Elderly Patients}

Increasing age seems to affect the pharmacokinetic profile of etomidate. In a study conducted by Arden et al. [53], etomidate doses required to achieve a certain EEG endpoint were significantly lower in elderly patients. This appears to be mostly caused by a change in pharmacokinetics with increasing age, such as a decrease in initial volume distribution and clearance, rather than a change in brain sensitivity. The decrease in initial distribution volume with increasing age implies that elderly patients are exposed to a higher initial etomidate blood concentration. Combined with a decrease in 
clearance in elderly patients, this can explain the reduction in required dose of etomidate [53].

Larsen et al. [106] compared the cardiovascular and myocardial effects of propofol and etomidate in elderly patients. They showed that both propofol and etomidate decrease blood pressure, heart rate, and cardiac index to the same extent. However, sympathetic responses to endotracheal intubation were much more blunted with propofol, with patients receiving etomidate showing a marked increase in arterial pressure. Therefore, although both drugs should be used with caution in fragile patients, propofol is slightly preferred by Larsen et al.

More recent studies compared etomidate to propofol in combination with either remifentanil or midazolam in elderly patients during endoscopy $[138,139]$. In a large study by Shen et al., etomidate-remifentanil was compared with propofol-remifentanil. It was found that etomidateremifentanil had a more stable hemodynamic profile than propofol-remifentanil. Although the incidence of myoclonus was higher in the etomidate group, this comprised a small group of $4.5 \%$ [138]. Lee et al. also reported that etomidatemidazolam was associated with fewer cardiopulmonary adverse events than propofol-midazolam in elderly patients undergoing a colonoscopy. However, etomidate-midazolam caused markedly more movement of the patients, disturbing the procedure [139]. Therefore, Lee recommends propofolmidazolam to be used in relatively healthy elderly patients and etomidate-midazolam.

\subsection{Renally/Hepatically Impaired Patients}

In general, the behavior of etomidate in renally and hepatically impaired patients is not well known. In patients with liver cirrhosis, etomidate clearance is not changed compared to non-cirrhotic patients. However, volumes of distribution and elimination half-life are significantly larger [140]. This appears to be due to a reduced plasma protein binding of etomidate in the presence of liver cirrhosis, as is also the case with renal failure.

Song et al. reported that in patients with obstructive jaundice, etomidate requirements are decreased compared with controls, with a negative correlation observed between total bilirubin and etomidate requirements [141]. It is hypothesized that this effect is caused by an enhancement of GABA synaptic transmission by bilirubin [142]. However, obstructive jaundice did not affect propofol requirement in a similar study by Song et al. [143]. Song et al. hypothesized that this can be explained by the specific binding of etomidate to the $\mathrm{GABA}_{\mathrm{A}}$ receptor, whereas propofol also acts on other receptors. Additionally, propofol can also be metabolized extrahepatically, whereas etomidate metabolism solely takes place in the liver [141].

\subsection{Electroconvulsive Therapy}

Etomidate is frequently used as a hypnotic drug for electroconvulsive therapy (ECT). Electroconvulsive therapy is a treatment in which seizures are electrically induced to treat selected psychiatric diseases in patients who do not respond sufficiently to pharmacotherapy. Most anesthetic agents possess anticonvulsant properties and therefore increase the threshold for the seizure induction and inhibit the spread of the seizure, thereby counteracting the effect of ECT [144]. Although etomidate also acts as an anticonvulsant, hypnotic doses have a minimal effect on the duration of ECT-induced seizures compared to equipotent doses of other anesthetic agents such as propofol, methohexital, or thiopental [144-147]. The relationship of the duration of ECT-induced seizures and etomidate does not seem to be dose dependent [148]. Of note is that in recent years, the relevance of the quality, rather than the quantity (i.e., duration), of the induced seizure is increasingly thought to determine its therapeutic efficacy [149].

\subsection{Hypercortisolism}

The adrenal suppression that is caused by etomidate has made it a useful drug in the treatment of Cushing's syndrome. A review by Preda et al. describing the studies and case reports in which etomidate was used in the management of severe Cushing's syndrome suggested that low doses of etomidate should be used in critically ill patients who needed a swift control of cortisol levels and where the only possible route of administration was parenteral. However, intensive care monitoring is necessary, as is regular control of serum cortisol levels [150]. Subsequent studies confirmed this suggestion [151]. Recent studies in patients with Cushing's syndrome who did not require intensive care unit monitoring suggested that they also might benefit from low doses of etomidate [152]. To retain the inhibition of steroidogenesis produced by etomidate, but abolish its hypnotic action, analogs of etomidate are currently being designed and investigated $[99,153]$.

\section{Future Perspectives}

Another novel etomidate analog currently in the pre-clinical stage of development is ET-26 hydrochloride. In vivo, ET-26 hydrochloride has stable hemodynamics and an anesthetic profile similar to etomidate [14, 154]. Adrenocortical suppression is reported to be less than with etomidate and in an in vivo sepsis model, it is virtually non-existent, with rats having a higher survival rate with ET-26 hydrochloride than with etomidate [155]. Pre-clinical pharmacologic studies showed that metabolism mainly takes place in the liver 
with hydroxylation being the main mechanism. It is excreted mostly through the kidney. Distribution is shown to be rapid $[156,157]$. No clinical trials were found to be registered as of September 2020, but apparently, it is ready to be studied in a phase I clinical trial [157].

While the development of ABP-700 was discontinued by The Medicines Company in 2017, it was restarted in 2020 with funding by Mass General Brigham (Boston, MA, USA), the assembly of an ABP-700 development team, and a Pre-IND submission to the US Food and Drug Administration (personal communication, D. Raines, Department of Anesthesia, Critical Care, and Pain Medicine, Massachusetts General Hospital, Boston, MA, USA, 15 February, 2021).

\section{Conclusions}

Etomidate is a $\mathrm{GABA}_{\mathrm{A}}$ receptor agonist that is used for the induction of anesthesia. It has favorable hemodynamic and respiratory properties in that it does not produce cardiovascular or respiratory depression. However, it causes suppression of the adrenal axis and is therefore not suitable for prolonged infusions. The pharmacokinetic properties of etomidate are not recently described, as most pharmacokinetic studies were performed almost $40-50$ years ago. These report that etomidate is metabolized by hepatic esterases, which causes hydrolysis into a carboxylic acid and methanol. Clearance and initial volume of distribution decrease with age. Despite etomidate being on the market for almost 50 years, few well-designed population pharmacokinetic models currently exist, and even fewer combined PK-PD models. This is probably in part because of the occurrence of adrenocortical suppression and in part because of the limited clinical use of etomidate as a bolusonly agent. A well-designed population PK-PD model is warranted to identify relevant covariates and optimize dosing of etomidate in various patient groups. To retain the beneficial hemodynamic and respiratory profile of etomidate but eliminate its adrenocortical suppressive effects, analogs of etomidate have been developed. One of them, ABP-700, is under clinical development. It has a pharmacokinetic profile similar to etomidate, but with smaller volumes of distribution and a rapid clearance. Another analog of etomidate currently in pre-clinical development is ET-26 hydrochloride.

One of the most striking adverse effects of both etomidate and its analog ABP-700 is the occurrence of IMM. The origin of these movements is not yet clear, although it does not seem to be an epileptogenic one. More likely is the hypothesis that these are the result of fast pharmacokinetic properties and a disequilibrium between several cortical structures.
More research is needed to identify the mechanism behind these movements.

\section{Declarations}

Funding Only departmental funding was used to assist with the preparation of this review. Open access publishing was provided by institutional funding of the University of Groningen.

Conflicts of Interest/Competing Interests Beatrijs I. Valk has no conflicts of interest that are directly relevant to the content of this article. Michel M.R.F. Struys's research group/department received (over the last 3 years) research grants and consultancy fees from The Medicines Company (Parsippany, NJ, USA), Masimo (Irvine, CA, USA), Becton-Dickinson (Eysins, Switzerland), Fresenius (Bad Homburg, Germany), Dräger (Lübeck, Germany), Paion (Aachen, Germany), Medtronic (Dublin, Ireland), and Medcaptain Europe (Andelst, The Netherlands). He receives royalties on intellectual property from Demed Medical (Temse, Belgium) and Ghent University (Ghent, Belgium). $\mathrm{He}$ is an editorial board member and director for the British Journal of Anaesthesia and an associate editor for Anesthesiology.

Ethics Approval Not applicable.

Consent to Participate Not applicable.

Consent for Publication Not applicable.

Availability of Data and Material Data sharing is not applicable to this article as no datasets were generated or analyzed during the current study. The generated library is available upon request to the corresponding author.

Code Availability Not applicable.

Authors' Contributions BIV: literature search and analysis, writing, and critical revision of the manuscript. MMRFS: conceptualization and writing and critical revision of the manuscript.

Open Access This article is licensed under a Creative Commons Attribution-NonCommercial 4.0 International License, which permits any non-commercial use, sharing, adaptation, distribution and reproduction in any medium or format, as long as you give appropriate credit to the original author(s) and the source, provide a link to the Creative Commons licence, and indicate if changes were made. The images or other third party material in this article are included in the article's Creative Commons licence, unless indicated otherwise in a credit line to the material. If material is not included in the article's Creative Commons licence and your intended use is not permitted by statutory regulation or exceeds the permitted use, you will need to obtain permission directly from the copyright holder. To view a copy of this licence, visit http://creativecommons.org/licenses/by-nc/4.0/.

\section{References}

1. Godefroi EE, Janssen PAJ, Van der Eycken CAM, Van Heertum AHMT, Niemegeers CJE. DL-1-(1-arylalkyl)imidazole-5-carboxylate esters: a novel type of hypnotic agents. J Med Chem. $1965 ; 8: 220-3$. 
2. Doenicke AW. Etomidate, a new intravenous hypnotic. Acta Anaesthesiol Belg. 1974;25:307-15.

3. Janssen PA, Niemegeers CJ, Marsboom RP. Etomidate, a potent non-barbiturate hypnotic. Intravenous etomidate in mice, rats, guinea-pigs, rabbits and dogs. Arch Int Pharmacodyn Ther. 1975;214:92-132.

4. Kay B. A dose-response relationship for etomidate, with some observations on cumulation. Br J Anaesth. 1976;48:213-6.

5. Criado A, Maseda J, Navarro E, Escarpa A, Aveixo F, Escarpa MA, et al. Induction of anaesthesia with etomidate: haemodynamic study of 36 patients. Br J Anaesth. 1980;52:803.

6. Egan ED, Johnson KB. The influence of hemorrhagic shock on the disposition and effects of intravenous anesthetics: a narrative review. Anesth Analg. 2020;130:1320-30.

7. Yelavich PM, Holmes McK. C. Etomidate: a foreshortened clinical trial. Anaesth Intensive Care. 1980;8:479-83.

8. Meinck HM, Möhlenhof O, Kettler D. Neurophysiological effects of etomidate, a new short-acting hypnotic. Electroencephalogr Clin Neurophysiol. 1980;50:515-22.

9. Ledingham IM, Watt I. Influence of sedation on mortality in critically ill multiple trauma patients. Lancet. 1983;321:1270.

10. Wagner RL, White PF, Kan PB, Rosenthal MH, Feldman D. Inhibition of adrenal steroidogenesis by the anesthetic etomidate. N Engl J Med. 1984;310:1415-21.

11. Allolio B, Stuttmann R, Leonhard U, Fischer H, Winkelmann W. Adrenocortical suppression by a single induction dose of etomidate. Klin Wochenschr. 1984;62:1014-7.

12. Cotten JF, Husain SS, Forman SA, Miller KW, Kelly EW, Nguyen HH, et al. Methoxycarbonyl-etomidate: a novel rapidly metabolized and ultra-short-acting etomidate analogue that does not produce prolonged adrenocortical suppression. Anesthesiology. 2009;111:240-9.

13. Cotten JF, Forman SA, Laha JK, Cuny GD, Husain SS, Miller $\mathrm{KW}$, et al. Carboetomidate: a pyrrole analog of etomidate designed not to suppress adrenocortical function. Anesthesiology. 2010;112:637-44.

14. Wang B, Yang J, Chen J, Kang Y, Yang LH, Liu J, et al. An etomidate analogue with less adrenocortical suppression, stable hemodynamics, and improved behavioral recovery in rats. Anesth Analg. 2017;125:442-50.

15. Mendeley desktop v1.19.6. London: Elsevier Ltd; 2020.

16. Janssen PA, Niemegeers CJ, Schellekens KH, Lenaerts FM. Etomidate, R-(+)-ethyl-1-(-methyl-benzyl)imidazole-5-carboxylate (R 16659), a potent, short-acting and relatively atoxic intravenous hypnotic agent in rats. Arzneimittelforschung. 1971;21:1234-43.

17. Holdcroft A, Morgan M, Whitwam JG, Lumley J, Holdcroft A, Jean Lumley M. Effect of dose and premedication on induction complications with etomidate. Br J Anaesth. 1976;48:199-205.

18. Doenicke A, Roizen MF, Nebauer AE, Kugler A, Hoernecke R, Beger-Hintzen $\mathrm{H}$. A comparison of two formulations for etomidate, 2-hydroxypropyl- $\beta$-cyclodextrin (HPCD) and propylene glycol. Anesth Analg. 1994;79:933-9.

19. Doenicke A, Roizen MF, Hoernecke R, Mayer M, Ostwald P, Foss J. Haemolysis after etomidate: comparison of propylene glycol and lipid formulations. Br J Anaesth. 1997;79:386-8.

20. Amidate ${ }^{\mathrm{TM}}$ (etomidate injection, USP) [package insert]. Hospira Inc., Lake Forest, IL, USA. 2017. https://www.accessdata.fda. gov/drugsatfda_docs/label/2017/018227s032lbl.pdf. Accessed 17 May 2021.

21. Streisand JB, Jaarsma RL, Gay MA, Badger MJ, Maland L, Nordbrock E, et al. Oral transmucosal etomidate in volunteers. Anesthesiology. 1998;88:89-95.

22. Linton DM, Thornington RE. Etomidate as a rectal induction agent. Part II. A clinical study in children. South Afr Med J. 1983;64:309-10.
23. Valk BI, Absalom AR, Meyer P, Meier S, den Daas I, van Amsterdam K, et al. Safety and clinical effect of i.v. infusion of cyclopropyl-methoxycarbonyl etomidate (ABP-700), a soft analogue of etomidate, in healthy subjects. Br J Anaesth. 2018;120:1401-11.

24. Struys MMRF, Valk BI, Eleveld DJ, Absalom AR, Meyer P, Meier $\mathrm{S}$, et al. A phase 1, single-center, double-blind, placebo-controlled study in healthy subjects to assess the safety, tolerability, clinical effects, and pharmacokinetics-pharmacodynamics of intravenous cyclopropyl-methoxycarbonylmetomidate (ABP-700) after a single ascending bolus dose. Anesthesiology. 2017;127:20-35.

25. Bodor N, Buchwald P. Soft drug design: general principles and recent applications. Med Res Rev. 2000;20:58-101.

26. Roumen L, Sanders MPA, Pieterse K, Hilbers PAJ, Plate R, Custers E, et al. Construction of 3D models of the CYP11B family as a tool to predict ligand binding characteristics. J Comput Aid Mol Des. 2007;21:455-71.

27. Cotten JF, Le Ge R, Banacos N, Pejo E, Husain SS, Williams JH, et al. Closed-loop continuous infusions of etomidate and etomidate analogs in rats: a comparative study of dosing and the impact on adrenocortical function. Anesthesiology. 2011;115:764-73.

28. Le Ge R, Pejo E, Haburcak M, Husain SS, Forman SA, Raines DE. Pharmacological studies of methoxycarbonyl etomidate's carboxylic acid metabolite. Anesth Analg. 2012;115:305-8.

29. Pejo E, Ge R, Banacos N, Cotten JF, Husain SS, Raines DE. Electroencephalographic recovery, hypnotic emergence, and the effects of metabolite after continuous infusions of a rapidly metabolized etomidate analog in rats. Anesthesiology. 2012;116:1057-65.

30. Husain SS, Pejo E, Ge R, Raines DE. Modifying methoxycarbonyl etomidate inter-ester spacer optimizes in vitro metabolic stability and in vivo hypnotic potency and duration of action. Anesthesiology. 2012;117:1027-36.

31. Ge R, Pejo E, Husain SS, Cotten JF, Raines DE. Electroencephalographic and hypnotic recoveries after brief and prolonged infusions of etomidate and optimized soft etomidate analogs. Anesthesiology. 2012;117:1037-43.

32. Ge R, Pejo E, Cotten JF, Raines DE. Adrenocortical suppression and recovery after continuous hypnotic infusion: etomidate versus its soft analogue cyclopropyl-methoxycarbonyl metomidate. Crit Care. 2013;17:R20.

33. Campagna JA, Pojasek K, Grayzel D, Randle J, Raines DE. Advancing novel anesthetics: pharmacodynamic and pharmacokinetic studies of cyclopropyl-methoxycarbonyl metomidate in dogs. Anesthesiology. 2014;121:1203-16.

34. Preziosi P, Vacca M. Etomidate and corticotrophic axis. Arch Int Pharmacodyn Ther. 1982;256:308-10.

35. Mckee JI, Finlay WEI. Cortisol replacement in severely stressed patients. Lancet. 1983;321:484.

36. Wagner RL, White PF. Etomidate inhibits adrenocortical function in surgical patients. Anesthesiology. 1984;61:647-51.

37. Fragen RJ, Shanks CA, Molteni A, Avram MJ. Effects of etomidate on hormonal responses to surgical stress. Anesthesiology. 1984;61:652-6.

38. Wannscher M, Tønessen E, Hüttel M, Larsen K. Etomidate infusion and adrenocortical function: a study in elective surgery. Acta Anaesthesiol Scand. 1985;29:483-5.

39. Owen H, Spence AA. Etomidate. Br J Anaesth. 1984;56:555-7.

40. Longnecker DE. Stress free: to be or not to be? Anesthesiology. 1984;61:643-4.

41. Doenicke AW, Roizen MF, Hoernecke R, Lorenz W, Ostwald P. Solvent for etomidate may cause pain and adverse effects. Br J Anaesth. 1999;83:464-70.

42. Nyman Y, Von Hofsten K, Palm C, Eksborg S, Lönnqvist PA. Etomidate-Lipuro is associated with considerably less injection 
pain in children compared with propofol with added lidocaine. Br J Anaesth. 2006;97:536-45.

43. Matta JA, Cornett PM, Miyares RL, Abe K, Sahibzada N, Ahern GP. General anesthetics activate a nociceptive ion channel to enhance pain and inflammation. Proc Natl Acad Sci USA. 2008;105:8784-9.

44. St Pierre M, Dunkel M, Rutherford A, Hering W. Does etomidate increase postoperative nausea? A double-blind controlled comparison of etomidate in lipid emulsion with propofol for balanced anaesthesia. Eur J Anaesthesiol. 2000;17:634-41.

45. Kaneda K, Yamashita S, Woo S, Han TH. Population pharmacokinetics and pharmacodynamics of brief etomidate infusion in healthy volunteers. J Clin Pharmacol. 2011;51:482-91.

46. Meuldermans WEG, Heykants JJP. The plasma protein binding and distribution of etomidate in dog, rat and human blood. Arch Int Pharmacodyn Ther. 1976;221:150-62.

47. Fresno L, Andaluz A, Moll X, Cristofol C, Arboix M, García F. Placental transfer of etomidate in pregnant ewes after an intravenous bolus dose and continuous infusion. Vet $\mathrm{J}$. 2008;175:395-402.

48. Van Hamme MJ, Ghoneim MM, Ambre JJ. Pharmacokinetics of etomidate, a new intravenous anesthetic. Anesthesiology. 1978;49:274-7.

49. Fragen RJ, Avram MJ, Henthorn TK, Caldwell NJ. A Pharmacokinetically designed etomidate infusion regimen for hypnosis. Anesth Analg. 1983;62:654-60.

50. Hebron BS, Edbrooke DL, Newby D., Mather SJ. Pharmacokinetics of etomidate associated with prolonged i.v. infusion. $\mathrm{Br}$ J Anaesth. 1983;55:281-7.

51. de Ruiter G, Popescu DT, de Boer AG, Smeekens JB, Breimer DD. Pharmacokinetics of etomidate in surgical patients. Arch Int Pharmacodyn Ther. 1981;249:180-8.

52. Schüttler J, Schwilden H, Stoeckel H. Infusion strategies to investigate the pharmacokinetics and pharmacodynamics of hypnotic drugs: etomidate as an example. Eur J Anaesthesiol. 1985;2:133-42.

53. Arden JR, Holley FO, Stanski DR. Increased sensitivity to etomidate in the elderly: initial distribution versus altered brain response. Anesthesiology. 1986;65:19-27.

54. Ghoneim MM, Van Hamme MJ. Hydrolysis of etomidate. Anesthesiology. 1979;50:227-9.

55. Carlos R, Calvo R, Erill S. Plasma protein binding of etomidate in patients with renal failure or hepatic cirrhosis. Clin Pharmacokinet. 1979;4:144-8.

56. Lin L, Zhang JW, Huang Y, Bai J, Cai MH, Zhang MZ. Population pharmacokinetics of intravenous bolus etomidate in children over 6 months of age. Paediatr Anaesth. 2012;22:318-26.

57. Su F, El-Komy MH, Hammer GB, Frymoyer A, Cohane CA, Drover DR. Population pharmacokinetics of etomidate in neonates and infants with congenital heart disease. Biopharm Drug Dispos. 2015;36:104-14.

58. Shen Y, Cai MH, Ji W, Bai J, Huang Y, Sun Y, et al. Unrepaired tetralogy of Fallot-related pathophysiologic changes reduce systemic clearance of etomidate in children. Anesth Analg. 2016;123:722-30.

59. Valk BI, Eleveld DJ, Meyer P, Meier S, den Daas I, van Amsterdam K, et al. Modeling the effect of excitation on depth of anesthesia monitoring in $\gamma$-aminobutyric acid type A receptor agonist ABP-700. Anesthesiology. 2021;134(1):35-51.

60. Lallemand MA, Lentschener C, Mazoit JX, Bonnichon P, Manceau I, Ozier Y. Bispectral index changes following etomidate induction of general anaesthesia and orotracheal intubation. Br J Anaesth. 2003;91:341-6.

61. Kuizenga K, Wierda JMKH, Kalkman CJ. Biphasic EEG changes in relation to loss of consciousness during induction with thiopental, propofol, etomidate, midazolam or sevoflurane. Br J Anaesth. 2001;86:354-60.

62. Forman SA. Clinical and molecular pharmacology of etomidate. Anesthesiology. 2011;114:695-707.

63. Rudolph U, Antkowiak B. Molecular and neuronal substrates for general anaesthetics. Nat Rev Neurosci. 2004;5:709-20.

64. Bormann J. The, "ABC" of GABA receptors. Trends Pharmacol Sci. 2000;21:16-9.

65. Li GD, Chiara DC, Sawyer GW, Husain SS, Olsen RW, Cohen JB. Identification of a GABAA receptor anesthetic binding site at subunit interfaces by photolabeling with an etomidate analog. J Neurosci. 2006;26:11599-605.

66. Jurd R, Arras M, Lambert S, Drexler B, Siegwart R, Crestani F, et al. General anesthetic actions in vivo strongly attenuated by a point mutation in the GABA(A) receptor beta3 subunit. FASEB J. 2003;17:250-2.

67. Hill-Venning C, Belelli D, Peters JA, Lambert JJ. Subunitdependent interaction of the general anaesthetic etomidate with the $\gamma$-aminobutyric acid type A receptor. Br J Pharmacol. 1997;120:749-56.

68. Weir CJ, Mitchell SJ, Lambert JJ. Role of GABA A receptor subtypes in the behavioural effects of intravenous general anaesthetics. Br J Anaesth. 2017;119:1167-75.

69. Sieghart W. Structure and pharmacology of gamma-aminobutyric acidA receptor subtypes. Pharmacol Rev. 1995;47:181-234.

70. Ge R, Pejo E, Gallin H, Jeffrey S, Cotten JF, Raines DE. The pharmacology of cyclopropyl-methoxycarbonyl metomidate: a comparison with propofol. Anesth Analg. 2014;118:563-7.

71. Adapa R. Consciousness and anesthesia. In: Absalom AR, Mason $\mathrm{KP}$, editors. Total intravenous anesthesia and target controlled infusion. Cham, Switzerland: Springer International Publishing; 2017: p. 63-78.

72. Saper CB, Chou TC, Scammell TE. The sleep switch: hypothalamic control of sleep and wakefulness. Trends Neurosci. 2001;24:726-31.

73. Saper CB, Fuller PM, Pedersen NP, Lu J, Scammell TE. Sleep state switching. Neuron. Neuron. 2010;68:1023-42.

74. Moruzzi G, Magoun HW. Brain stem reticular formation and activation of the EEG. Electroencephalogr Clin Neurophysiol. 1949;1:455-73.

75. Leung LS, Luo T, Ma J, Herrick I. Brain areas that influence general anesthesia. Prog Neurobiol. 2014;122:24-44.

76. Fiset P, Paus T, Daloze T, Plourde G, Meuret P, Bonhomme V, et al. Brain mechanisms of propofol-induced loss of consciousness in humans: a positron emission tomographic study. J Neurosci. 1999;19:5506-13.

77. Mashour GA, Alkire MT. Consciousness, anesthesia, and the thalamocortical system. Anesthesiology. 2013;118:13-5.

78. Detsch O, Vahle-Hinz C, Kochs E, Siemers M, Bromm B. Isoflurane induces dose-dependent changes of thalamic somatosensory information transfer. Brain Res. 1999;829:77-89.

79. Velly LJ, Rey MF, Bruder NJ, Gouvitsos FA, Witjas T, Regis JM, et al. Differential dynamic of action on cortical and subcortical structures of anesthetic agents during induction of anesthesia. Anesthesiology. 2007;107:202-12.

80. Alkire MT, Haier RJ, Fallon JH. Toward a unified theory of narcosis: brain imaging evidence for a thalamocortical switch as the neurophysiologic basis of anesthetic-induced unconsciousness. Conscious Cogn. 2000;9:370-86.

81. Brown EN, Lydic R, Schiff ND. General anesthesia, sleep, and coma. N Engl J Med. 2010;363:2638-50.

82. Dahaba AA. Different conditions that could result in the bispectral index indicating an incorrect hypnotic state. Anesth Analg. 2005;101:765-73. 
83. Hueter L, Schwarzkopf K, Simon M, Bredle D, Fritz H. Pretreatment with sufentanil reduces myoclonus after etomidate. Acta Anaesthesiol Scand. 2003;47:482-4.

84. Lu Z, Fang J, Zhu J, Liang B, Li F, Jiang S, et al. Intravenous dezocine pretreatment reduces the incidence and intensity of myoclonus induced by etomidate. J Anesth. 2014;28:944-7.

85. He L, Ding Y, Chen H, Qian Y, Li Z. Dezocine pretreatment prevents myoclonus induced by etomidate: a randomized, doubleblinded controlled trial. J Anesth. 2015;29:143-5.

86. Isitemiz I, Uzman S, Toptaş M, Vahapoglu A, Gül YG, Inal FY, et al. Prevention of etomidate-induced myoclonus: which is superior: fentanyl, midazolam, or a combination? A retrospective comparative study. Med Sci Monit. 2014;20:262-7.

87. Hüter L, Schreiber T, Gugel M, Schwarzkopf K. Low-dose intravenous midazolam reduces etomidate-induced myoclonus: a prospective, randomized study in patients undergoing elective cardioversion. Anesth Analg. 2007;105:1298-302.

88. Schwarzkopf KRG, Hueter L, Simon M, Fritz HG. Midazolam pretreatment reduces etomidate-induced myoclonic movements. Anaesth Intensive Care. 2003;31:18-20.

89. Mizrak A, Koruk S, Bilgi M, Kocamer B, Erkutlu I, Ganidagli S, et al. Pretreatment with dexmedetomidine or thiopental decreases myoclonus after etomidate: a randomized, double-blind controlled trial. J Surg Res. 2010;159:e11-6.

90. Luan HF, Zhao ZB, Feng JY, Cui JZ, Zhang XB, Zhu P, et al. Prevention of etomidate-induced myoclonus during anesthetic induction by pretreatment with dexmedetomidine. Braz J Med Biol Res. 2015;48:186-90.

91. Gultop F, Akkaya T, Bedirli N, Gumus H. Lidocaine pretreatment reduces the frequency and severity of myoclonus induced by etomidate. J Anesth. 2010;24:300-2.

92. Guler A, Satilmis T, Akinci SB, Celebioglu B, Kanbak M. Magnesium sulfate pretreatment reduces myoclonus after etomidate. Anesth Analg. 2005;101:705-9.

93. Doenicke AW, Roizen MF, Kugler J, Kroll H, Foss J, Ostwald P. Reducing myoclonus after etomidate. Anesthesiology. 1999;90:113-9.

94. Nyman Y, Von Hofsten K, Ritzmo C, Eksborg S, Lnnqvist PA. Effect of a small priming dose on myoclonic movements after intravenous anaesthesia induction with Etomidate-Lipuro in children. Br J Anaesth. 2011;107:225-8.

95. Modica PA, Tempelhoff R, White PF. Pro- and anticonvulsant effects of anesthetics (Part II). Anesth Analg. 1990;70:433-44.

96. Kugler J, Doenicke A, Laub M. The EEG after etomidate. In: Doenicke A, editor. Etomidate: an intravenous hypnotic agent. Berlin: Springer; 1977. p. 31-48.

97. Reddy RV, Moorthy SS, Dierdorf SF, Deitch RD, Link L. Excitatory effects and electroencephalographic correlation of etomidate, thiopental, methohexital, and propofol. Anesth Analg. 1993;77:1008-11.

98. Valk BI, McGrath M, Lehoux D, Zerler B, Marota JJA, Raines DE. Toxicologic and inhibitory receptor actions of the etomidate analog ABP-700 and its metabolite CPM-acid. Anesthesiology. 2019;131:287-304

99. McGrath M, Ma C, Raines DE. Dimethoxy-etomidate: a nonhypnotic etomidate analog that potently inhibits steroidogenesis. $\mathrm{J}$ Pharmacol Exp Ther. 2018;364:229-37.

100. Ebert TJ, Muzi M, Berens R, Goff D, Kampine JP. Sympathetic responses to induction of anesthesia in humans with propofol or etomidate. Anesthesiology. 1992;76:725-33.

101. Paris A, Philipp M, Tonner PH, Steinfath M, Lohse M, Scholz J, et al. Activation of $\alpha 2 \mathrm{~B}$-adrenoceptors mediates the cardiovascular effects of etomidate. Anesthesiology. 2003;99:889-95.

102. Gooding JM, Corssen G. Effect of etomidate on the cardiovascular system. Anesth Analg. 1977;56:717-9.
103. Gooding JM, Weng JT, Smith RA, Berninger GT, Kirby RR. Cardiovascular and pulmonary responses following etomidate induction of anesthesia in patients with demonstrated cardiac disease. Anesth Analg. 1979;58:40-1.

104. Brussel T, Theissen JL, Vigfusson G, Lunkenheimer PP, Van Aken H, Lawin P. Hemodynamic and cardiodynamic effects of propofol and etomidate: negative inotropic properties of propofol. Anesth Analg. 1989;69:35-40.

105. Colvin MP, Savege TM, Newland PE, Weaver EJM, Waters AF, Brookes JM, et al. Cardiorespiratory changes following induction of anaesthesia with etomidate in patients with cardiac disease. Br J Anaesth. 1979;51:551-6.

106. Larsen R, Rathgeber J, Bagdahn A, Lange H, Rieke H. Effects of propofol on cardiovascular dynamics and coronary blood flow in geriatric patients: a comparison with etomidate. Anaesthesia. 1988;43:25-31.

107. Möller Petrun A, Kamenik M. Bispectral index-guided induction of general anaesthesia in patients undergoing major abdominal surgery using propofol or etomidate: a double-blind, randomized, clinical trial. Br J Anaesth. 2013;110:388-96.

108. De Paepe P, Belpaire FM, Rosseel MT, Van Hoey G, Boon PA, Buylaert WA. Influence of hypovolemia on the pharmacokinetics and the electroencephalographic effect of propofol in the rat. Anesthesiology. 2000;93:1482-90.

109. Johnson KB, Egan TD, Layman J, Kern SE, White JL, McJames SW. The influence of hemorrhagic shock on etomidate: a pharmacokinetic and pharmacodynamic analysis. Anesth Analg. 2003;96:1360-8.

110. Morgan M, Lumley J, Whitwam JG. Respiratory effects of etomidate. Br J Anaesth. 1977;49:233-6.

111. Choi SD, Spaulding BC, Gross JB, Apfelbaum JL. Comparison of the ventilatory effects of etomidate and methohexital. Anesthesiology. 1985;62:442-7.

112. Guldager H, Søndergaard I, Jensen FM, Cold G. Basophil histamine release in asthma patients after in vitro provocation with althesin and etomidate. Acta Anaesthesiol Scand. 1985;29:352-3.

113. Doenicke A, Lorenz W, Beigl R, Bezechy H, Uhlig G, Kalmar $\mathrm{L}$, et al. Histamine release after intravenous application of short-acting hypnotics. Br J Anaesth. 1973;45:1097.

114. Jackson WL. Should we use etomidate as an induction agent for endotracheal intubation in patients with septic shock? A critical appraisal. Chest. 2005;127:1031-8.

115. Walls RM, Murphy MF. Clinical controversies: etomidate as an induction agent for endotracheal intubation in patients with sepsis: continue to use etomidate for intubation of patients with septic shock. Ann Emerg Med. 2008;52:13-4.

116. Absalom A, Pledger D, Kong A. Adrenocortical function in critically ill patients $24 \mathrm{~h}$ after a single dose of etomidate. Anaesthesia. 1999;54:861-7.

117. Cherfan AJ, Arabi YM, Al-Dorzi HM, Kenny LP. Advantages and disadvantages of etomidate use for intubation of patients with sepsis. Pharmacotherapy. 2012;32:475-82.

118. Annane D, Sébille V, Charpentier C, Bollaert PE, François B, Korach JM, et al. Effect of treatment with low doses of hydrocortisone and fludrocortisone on mortality in patients with septic shock. JAMA. 2002;288:862-71.

119. Annane D, Sebille V, Bellissant E. Corticosteroids for patients with septic shock. JAMA. 2003;289:43.

120. Sprung CL, Annane D, Keh D, Moreno R, Singer M, Freivogel $\mathrm{K}$, et al. Hydrocortisone therapy for patients with septic shock. N Engl J Med. 2008;358:111-24.

121. Lipiner-Friedman D, Sprung CL, Laterre PF, Weiss Y, Goodman SV, Vogeser M, et al. Adrenal function in sepsis: the retrospective Corticus cohort study. Crit Care Med. 2007;35:1012-8. 
122. Cuthbertson BH, Sprung CL, Annane D, Chevret S, Garfield M, Goodman S, et al. The effects of etomidate on adrenal responsiveness and mortality in patients with septic shock. Intensive Care Med. 2009;35:1868-76.

123. Tekwani KL, Watts HF, Rzechula KH, Sweis RT, Kulstad EB. A prospective observational study of the effect of etomidate on septic patient mortality and length of stay. Acad Emerg Med. 2009;16:11-4.

124. Hildreth AN, Mejia VA, Maxwell RA, Smith PW, Dart BW, Barker DE. Adrenal suppression following a single dose of etomidate for rapid sequence induction: a prospective randomized study. J Trauma. 2008;65:573-9.

125. Komatsu R, You J, Mascha EJ, Sessler DI, Kasuya Y, Turan A. Anesthetic induction with etomidate, rather than propofol, is associated with increased 30-day mortality and cardiovascular morbidity after noncardiac surgery. Anesth Analg. 2013;117:1329-37.

126. Jabre P, Combes X, Lapostolle F, Dhaouadi M, Ricard-Hibon A, Vivien B, et al. Etomidate versus ketamine for rapid sequence intubation in acutely ill patients: a multicentre randomised controlled trial. Lancet. 2009;374:293-300.

127. Ray DC, Hay AW, McKeown DW. Induction drug and outcome of patients admitted to the intensive care unit after emergency laparotomy. Eur J Anaesthesiol. 2010;27:481-5.

128. Van Berkel MA, Exline MC, Cape KM, Ryder LP, Phillips G, Ali NA, et al. Increased incidence of clinical hypotension with etomidate compared to ketamine for intubation in septic patients: a propensity matched analysis. J Crit Care. 2017;38:209-14.

129. Groth CM, Acquisto NM, Khadem T. Current practices and safety of medication use during rapid sequence intubation. J Crit Care. 2018;45:65-70.

130. Lyon RM, Perkins ZB, Chatterjee D, Lockey DJ, Russell MQ. Significant modification of traditional rapid sequence induction improves safety and effectiveness of pre-hospital trauma anaesthesia. Crit Care. 2015;19:134.

131. Du Y, Chen YJ, He B, Wang YW. The effects of single-dose etomidate versus propofol on cortisol levels in pediatric patients undergoing urologic surgery: a randomized controlled trial. Anesth Analg. 2015;121:1580-5.

132. Gu H, Zhang M, Cai M, Liu J. Comparison of adrenal suppression between etomidate and dexmedetomidine in children with congenital heart disease. Med Sci Monit. 2015;21:1569-76.

133. Sokolove PE, Price DD, Okada P. The safety of etomidate for emergency rapid sequence intubation of pediatric patients. Pediatr Emerg Care. 2000;16:18-21.

134. Bramwell KJ, Haizlip J, Pribble C, VanDerHeyden TC, Witte $\mathrm{M}$. The effect of etomidate on intracranial pressure and systemic blood pressure in pediatric patients with severe traumatic brain injury. Pediatr Emerg Care. 2006;22:90-3.

135. Mandt MJ, Roback MG, Bajaj L, Galinkin JL, Gao D, Wathen JE. Etomidate for short pediatric procedures in the emergency department. Pediatr Emerg Care. 2012;28:898-904.

136. Dhawan N, Chauhan S, Kothari SS, Kiran U, Das S, Makhija N. Hemodynamic responses to etomidate in pediatric patients with congenital cardiac shunt lesions. J Cardiothorac Vasc Anesth. 2010;24:802-7.

137. Malik M, Malik V, Chauhan S, Dhawan N, Kiran U. Ketamineetomidate for children undergoing cardiac catheterization. Asian Cardiovasc Thorac Ann. 2011;19:143-8.

138. Shen XC, Ao X, Cao Y, Lan L, Liu XM, Sun WJ, et al. Etomidate-remifentanil is more suitable for monitored anesthesia care during gastroscopy in older patients than propofol-remifentanil. Med Sci Monit. 2015;21:1-8.

139. Lee JM, Min G, Lee JM, Kim SH, Choi HS, Kim ES, et al. Efficacy and safety of etomidate-midazolam for screening colonoscopy in the elderly. Medicine (Baltimore). 2018;97:e10635.
140. Beem H, Manger FW, Boxtel C, Bentem N. Etomidate anaesthesia in patients with cirrhosis of the liver: pharmacokinetic data. Anaesthesia. 1983;38:61-2.

141. Song JC, Sun YM, Zhang MZ, Yang LQ, Tao TZ, Yu WF. The etomidate requirement is decreased in patients with obstructive jaundice. Anesth Analg. 2011;113:1028-32.

142. Shi HB, Kakazu Y, Shibata S, Matsumoto N, Nakagawa T, Komune S. Bilirubin potentiates inhibitory synaptic transmission in lateral superior olive neurons of the rat. Neurosci Res. 2006;55:161-70.

143. Song JC, Zhang MZ, Lu ZJ, Yang LQ, Song JG, Sun YM, et al. The effects of obstructive jaundice on the pharmacodynamics of propofol: does the sensitivity of intravenous anesthetics change among icteric patients? Acta Anaesthesiol Scand. 2009;53:1329-35.

144. Avramov MN, Husain MM, White PF. The comparative effects of methohexital, propofol, and etomidate for electroconvulsive therapy. Anesth Analg. 1995;81:596-602.

145. Wauquier A. Profile of etomidate: a hypnotic, anticonvulsant and brain protective compound. Anaesthesia. 1983;38 Suppl.:26-33.

146. Canbek O, Ipekcioglu D, Menges OO, Atagun MI, Karamustafalioglu N, Cetinkaya OZ, et al. Comparison of propofol, etomidate, and thiopental in anesthesia for electroconvulsive therapy: a randomized, double-blind clinical trial. J ECT. 2015;31:91-7.

147. Ayhan Y, Akbulut BB, Karahan S, Gecmez G, Öz G, Gurel $\mathrm{SC}$, et al. Etomidate is associated with longer seizure duration, lower stimulus intensity, and lower number of failed trials in electroconvulsive therapy compared with thiopental. J ECT. 2015;31:26-30.

148. Van Lammeren A, Dols A, Van De Ven PM, Greuters S, Boer $\mathrm{C}$, Loer SA, et al. Etomidate and seizure duration in electroconvulsive therapy is there a dose-dependent relation? J ECT. 2013;29:101-5.

149. Soehle M, Bochem J. Anesthesia for electroconvulsive therapy. Curr Opin Anaesthesiol. 2018;31:501-5.

150. Preda VA, Sen J, Karavitaki N, Grossman AB. Etomidate in the management of hypercortisolaemia in Cushing's syndrome: a review. Eur J Endocrinol. 2012;167:137-43.

151. Carroll TB, Peppard WJ, Herrmann DJ, Javorsky BR, Wang TS, Patel $\mathrm{H}$, et al. Continuous etomidate infusion for the management of severe cushing syndrome: validation of a standard protocol. $\mathrm{J}$ Endocr Soc. 2019;3:1-12.

152. Constantinescu SM, Driessens N, Lefebvre A, Furnica RM, Corvilain B, Maiter D. Etomidate infusion at low doses is an effective and safe treatment for severe Cushing's syndrome outside intensive care. Eur J Endocrinol. 2020;183:161-7.

153. McGrath M, Hofmann A, Raines DE. Behavioral and steroidogenic pharmacology of phenyl ring substituted etomidate analogs in rats. BMC Pharmacol Toxicol. 2019;20:48.

154. Wang B, Chen S, Yang J, Yang L, Liu J, Zhang W. ET-26 hydrochloride $(\mathrm{ET}-26 \mathrm{HCl})$ has similar hemodynamic stability to that of etomidate in normal and uncontrolled hemorrhagic shock (UHS) rats. PLoS One. 2017;12(8):e0183439.

155. Wang B, Jiang J, Yang J, Chen J, Zhu Z, Liu J, et al. Pharmacologic studies on ET-26 hydrochloride in a rat model of lipopolysaccharide-induced sepsis. Eur J Pharm Sci. 2017;109:441-5.

156. Zhang YJ, Deng C, Yang J, Gong D, Kang Y, Liu J, et al. Preclinical pharmacokinetics study of a novel intravenous anesthetic ET-26 hydrochloride. Curr Drug Metab. 2019;20:1073-81.

157. Zhang YJ, Deng CY, Gong DY, Kang Y, Liu J, Zhang WS. Preclinical safety evaluation of ET-26 hydrochloride, a novel intravenous anesthetic agent, in beagle dogs. J Appl Toxicol. 2020;40:679-90. 